\title{
Azotlu gübre dozlarının İtalyan çimi (Lolium italicum L.) çeşitlerinin ot kalitesine etkisi*
}

\author{
The effect of nitrogen fertilizer doses on herbage quality of Italian ryegrass (Lolium \\ italicum L.) cultivars \\ Ergül ÇOLAK ${ }^{1}$, Cengiz SANCAK ${ }^{2}$
}

${ }^{1}$ Gıda Tarım ve Hayvancılık Bakanlığı, Eğitim yayım ve Yayınlar Dairesi Başkanlığı, Yenimahalle/Ankara, Türkiye

${ }^{2}$ Ankara Üniversitesi, Ziraat Fakültesi, Tarla Bitkileri Bölümü, Ankara, Türkiye

Sorumlu yazar (Corresponding author): E. Çolak, e-posta (e-mail): ergul.colak@tarim.gov.tr

MAKALE BİLGISİ

Alınış tarihi 10 Nisan 2017

Düzeltilme tarihi 10 Ağustos 2017

Kabul tarihi 11 Ağustos 2017

\section{Anahtar Kelimeler:}

ADF

NDF

NYD

Ham kül oranı

Protein verimi

\begin{abstract}
ÖZ
$\mathrm{Bu}$ araștırma, İtalyan çimi çeșitlerinin yem kalitesini yükseltmede önemli bir potansiyeli olan azotlu gübrelerin değişik dozlarının etkilerini belirlemek üzere yapılmıştır. Orta Anadolu bölgesi kıraç koşullarında, 2008 ve 2009 yıllarında yürütülmüştür. Ankara Üniversitesi Ziraat Fakültesi Tarla Bitkileri Bölümü deneme tarlasında tesadüf bloklarında bölünmüş parseller deneme desenine göre 3 tekrarlamalı olarak kurulmuştur. Çalışmada azotlu gübre olarak amonyum nitrat (\% $33 \mathrm{~N}$ ) gübresinin $0,4,8,12,16,20$ ve $24 \mathrm{~kg} \mathrm{da}^{-1}$ dozları ve İtalyan çimi çeşidi olarak da Gemini, Tetraflorum ile Lolita kullanılmıştır. Erken ilkbaharda $30 \mathrm{~cm}$ sıra arası verilerek ekilen parsellerde gerektiği dönemlerde elle yabancı ot mücadelesi yapılmıştır. Parsellerdeki bitkiler çiçeklenme-başaklanma dönemine geldiğinde gözlemler ve hasat yapılmıştır. Çalışmadan elde edilen sonuçlara göre; İtalyan çimi çeşitleri arasında incelenen özelliklerden protein verimi, protein oranı, ham kül oranı, asitte çözünmeyen lif (ADF), nötr deterjanda çözünmeyen lif (NDF) ve nispi yem değeri (NYD) bakımından önemli farklılıklar belirlenmiștir. Azotlu gübre dozları protein oranı, protein verimi, ADF, NDF ve NYD üzerine etkili olmuştur. Ankara ve benzer koşullarında yapılacak İtalyan çimi yetiştiriciliğinde yüksek verim ve kaliteli yem elde etmek için Lolita çeşidine $8 \mathrm{~kg} \mathrm{da}^{-1}$ azot dozu uygulanması tavsiye edilebilir.
\end{abstract}

\section{ARTICLE INFO}

Received 10 April 2017

Received in revised form 10 August 2017 Accepted 11 August 2017

\section{Keywords:}

$\mathrm{ADF}$

NDF

RFV

Crude ash rate

Protein yield

\begin{abstract}
This research was conducted to determine the effects of different doses of nitrogen fertilizers which have a potential to increase the forage quality of Italian rye grass cultivars. It was carried out at the experimental area of Field Crops Department of Agricultural Faculty of Ankara University between the years of 2008 and 2009. The experiment was designed in split blocks with three replicates in the experimental plots of Field Crops Department of Agricultural Faculty of Ankara University. Nitrogen in ammonium nitrate (33\% N) form was applied on main blocks with the amount of $0,4,8,12,16,20$ and $24 \mathrm{~kg} \mathrm{da}^{-1}$ doses. Italian ryegrass cultivars Gemini, Tetraflorum and Lolita were places in sub-plots. Hand seeding was performed in early spring on the rows which was $30 \mathrm{~cm}$ apart each other. Weeds were taken out on the plots manually whenever needed. When the plants were at flowering stage, observations were made and plants were harvested for hay. According to the results; statistical differences were found among Italian rye grass cultivars for crude protein rate, protein yield, crude ash rate, acid detergent fiber (ADF), neutral detergent fiber (NDF) and relative feeding value (RFV). Nitrogen fertilizer doses affected crude protein rate, protein yield, crude ash rate, $\mathrm{ADF}, \mathrm{NDF}$ and RFV. In order to get higher quality forage in the Italian ryegrass cultivation in Ankara and similar conditions, Lolita cultivar and $8 \mathrm{~kg} \mathrm{da}^{-1}$ nitrogen fertilizer is recommended according to results of this research.
\end{abstract}

\section{'Bu çalışma Ergül Çolak'ın doktora tezinden hazırlanmıştır.}

\section{Giriş}

Ülkemiz hayvancılığında yüksek miktarlara ulaşan kaba yem gereksiniminin temin edilmesinde, çayır ve meraların işlevi

önemli olmakla birlikte öncelikli görülmeyip, ihtiyacın yarıdan fazlasının, tarla tarımı içerisinde üretilmesi gerekmektedir 
(Sabanc1 ve ark. 2010). Buğdaygil yem bitkileri kuru ot üretimi, silaj yapımı, toprak muhafazası ve yeşil alan tesisinde kullanılır (Serin ve Tan 1999). Yem bitkilerinden beklenen verimin alınabilmesi için bitkiler ihtiyaç duydukları dönemde uygun çeşit ve miktarlarda gübrelerle gübrelenmelidir. Buğdaygillerin en önemli özelliklerinden biri de gübrelemeye karşı verdikleri olumlu yüksek tepkidir. Gübreleme verimin yanında otun kalitesi ve otu yiyen hayvanın sağlığı açısından da önemlidir (Serin ve Tan 1999). Bitkilerde kuru maddenin büyük bir bölümünü oluşturan azot, bitki besin maddeleri arasında en önemli olanlardandır. Azot bitkilerde protein, klorofil, enzim ve vitaminlerin yapısında yer almaktadır. Proteinin \% 15-18'i azottan oluşmuştur (Zabunoğlu ve Karaçal 1986).

Güney Avrupa orijinli bir buğdaygil yem bitkisi olan İtalyan çimi, çim cinsi içerisinde, kültürü yapılan tek y1llık türdür (Gençkan 1983). Serin ve 1lıman iklim bölgelerinde, kışlık serin iklim tahıllarından arpa ve yulafin yem üretimi amacıyla yetiştirildiği alanlarda önemli bir alternatif kaba yem kaynağıdır. Normal koşullarda bir biçimde dekardan 1500-2500 $\mathrm{kg}$ arasında değişen yeşil ot ve $500-800 \mathrm{~kg}$ arasında kuru ot verimi elde edilebilmektedir. Sulu şartlarda veya yağışın yeterli olduğu bölgelerde 2-3 biçim alınarak 4-6 ton $\mathrm{da}^{-1}$ yeşil, $750-1500 \mathrm{~kg} \mathrm{da}^{-1}$ arasında kuru ot ürünü alınabilmektedir. Ülkemizde son yıllarda İtalyan çimi yetiştiriciliği, yem bitkilerine verilen teşviklerle yeni yeni benimsenmektedir (Baytekin ve ark. 2009).

İtalyan çimi yüksek büyüme hızına ve gübrelemede fazla azot absorbe etme yeteneğine sahiptir (Özkul ve ark. 2012). İtalyan çimi, ülkemizde istatistiklere 2014 yılında 4832 da ekiliş alanı ve 17023 ton üretim miktarı ile girmiştir. Bir yılda üç kattan fazla artarak 15196 da ekiliş alanı ve 58046 ton yeşil ot üretim miktarına ulaşmıştır (TÜİK 2015). İtalyan çimi bütün bu olumlu özellikleri nedeniyle, hayvancılığımızın ihtiyaç duyduğu kaliteli kaba yem üretimi amacıyla tarla tarımı içerisinde çok geniş yer alabilecek bir yem bitkisi olarak öne çıkmaktadır.

Yüksek verim ve kalitede hayvansal ürün elde edilmesi için hayvanlara yedirilecek yemin kalitesinin önceden bilinmesi, rasyon hazırlama ve ürün maliyetinin belirlenebilmesine olanak sağlamaktadır. Yem kalitesini belirlemede uzun yılardır uygulanan ham protein analizi yerine, hayvanların yem tüketim miktarı ve yemin sindirilme derecesini bilmeyi sağlayan lif analiz sistemini oluşturan ADF ve NDF önemli bir kalite ölçütü olarak kullanılmaktadır. Nispi Yem Değeri (NYD) ise yemin
ADF ve NDF değerlerinden hesaplanan ve yemin besin içeriği dışında sadece sayısal olarak değerini belirtmektedir (Yavuz ve ark. 2009).

$\mathrm{Bu}$ araştırma, Orta Anadolu şartlarında, İtalyan çiminin tetraploid çeşitlerinden Gemini, Tetraflorum ve Lolita çeşitlerine azotlu gübrenin $0,4,8,12,16,20$ ve $24 \mathrm{~kg} \mathrm{da}^{-1}$ dozları uygulanarak yürütülmüş ve ot kalitesi belirlenmeye çalışılmıştır.

\section{Materyal ve Yöntem}

\subsection{Araştırma Yeri ve Özellikleri}

Bu araştırma Ankara Üniversitesi Ziraat Fakültesi Tarla Bitkileri Bölümü deneme tarlalarında 2008 ve 2009 yıllarında yürütülmüştür. Araştırma yerinin denizden yüksekliğ̈i $891 \mathrm{~m}$ olup, $39^{0} 57^{\prime}$ kuzey enlem ve $32^{0} 53^{\prime}$ doğu boylam dereceleri arasında yer almaktadır.

Araştırma yerinin yağış, sıcaklık ve nispi nem uzun yıllar ortalaması ve denemenin yürütüldüğ̈̈ yıllara ait sıcaklık $\left({ }^{\circ} \mathrm{C}\right)$, aylık toplam yağı̧̧ $(\mathrm{mm})$ ve aylık ortalama nispi nem (\%) değerleri Çizelge 1'de gösterilmiştir.

Çizelge 1'de görüldügü gibi yıllık toplam yağış miktarı; denemenin kurulduğu ilk yılda (2008) $323.2 \mathrm{~mm}$, uzun yıllar ortalamasından düşük ve ikinci yılında (2009) $452.6 \mathrm{~mm}$, uzun yıllar ortalamasından (400.2 mm) daha yüksek olmuştur.

Yıllık ortalama sıcaklık değerleri uzun yıllar ortalaması $11.8^{\circ} \mathrm{C}$ iken 2008 y1lı ortalama sicaklık değeri $12.7^{\circ} \mathrm{C}$ ve 2009 y1lında $12.9^{\circ} \mathrm{C}$ ile uzun yillar ortalamasından yüksek olarak gerçekleşmiştir. Yıllık ortalama nispi nem değerleri ise, uzun y1llar ortalaması \% 61.4 iken 2008 y1lı ortalama nispi nem $\% 57.0$ ve 2009 yilında \% 59.9 ile uzun yıllar ortalamasından daha düşük olarak gerçekleşmiştir (DMİGM 2009).

Deneme alanından ekimden önce 0-30 ve 30-60 cm (Zabunoğlu ve Karaçal 1986) derinliklerden alınan toprak örnekleri, Ankara Üniversitesi Ziraat Fakültesi Toprak Bilimi ve Bitki Besleme Bölümü laboratuarında fiziksel ve kimyasal analize tabi tutulmuş (Güneş ve ark. 2010) ve sonuçları Çizelge 2'de verilmiştir. Araştırma alanının toprağ 1 killi-tınlı bir yapıdadır. Çalışma yapılan sahadaki toprak; tuzsuz, hafif alkali, orta kireçli, fosfor bakımından az, potasyum bakımından yüksek, organik madde bakımından az olarak değerlendirilmektedir (Eyüpoğlu 1999).

Çizelge 1. Araştırma alanının uzun yıllar (1975-2006) ortalaması ile 2008-2009 yıllarına ait iklim verileri (DMİGM 2009).

Table 1. The climate data of the experimental area in 2008, 2009 and long term period (1975-2006) (DMIGM 2009).

\begin{tabular}{|c|c|c|c|c|c|c|c|c|c|}
\hline \multirow[b]{2}{*}{ Aylar } & \multicolumn{3}{|c|}{ Aylık Toplam Yağış (mm) } & \multicolumn{3}{|c|}{ Aylık Ortalama Sicaklık $\left({ }^{\circ} \mathrm{C}\right)$} & \multicolumn{3}{|c|}{ Aylık Ortalama Nispi Nem (\%) } \\
\hline & Uzun Yillar & 2008 & 2009 & Uzun Yillar & 2008 & 2009 & Uzun Yillar & 2008 & 2009 \\
\hline Ocak & 40.6 & 20.1 & 61.5 & 0.3 & -4.0 & 2.4 & 76.2 & 76.3 & 76.2 \\
\hline Şubat & 33.4 & 6.5 & 69.5 & 1.8 & 0.1 & 4.3 & 70.8 & 68.9 & 75.4 \\
\hline Mart & 35.4 & 54.9 & 55.6 & 5.9 & 10.1 & 5.3 & 63.8 & 57.6 & 69.0 \\
\hline Nisan & 53.1 & 32.7 & 71.0 & 11.2 & 13.7 & 11.0 & 60.8 & 54.8 & 60.8 \\
\hline Mayis & 50.5 & 45.4 & 24.8 & 15.9 & 15.5 & 15.8 & 58.2 & 50.9 & 55.9 \\
\hline Haziran & 33.6 & 10.3 & 28.0 & 19.9 & 22.0 & 21.9 & 53.4 & 41.0 & 44.4 \\
\hline Temmuz & 15.2 & 0.0 & 13.9 & 23.3 & 24.9 & 23.6 & 47.7 & 35.7 & 46.6 \\
\hline Ağustos & 12.7 & 0.7 & 0.4 & 23.0 & 26.6 & 23.2 & 47.4 & 34.5 & 37.3 \\
\hline Eylül & 17.0 & 61.6 & 10.3 & 18.5 & 19.9 & 18.2 & 51.2 & 50.3 & 49.4 \\
\hline Ekim & 30.8 & 18.6 & 13.7 & 12.8 & 13.3 & 16.7 & 61.4 & 63.8 & 49.8 \\
\hline Kasım & 36.5 & 43.6 & 43.1 & 6.6 & 8.7 & 7.3 & 70.4 & 72.1 & 75.0 \\
\hline Aralık & 41.4 & 28.8 & 60.8 & 2.2 & 2.0 & 5.4 & 76.0 & 78.6 & 80.0 \\
\hline Ortalama & - & - & - & 11.8 & 12.7 & 12.9 & 61.4 & 57.0 & 59.92 \\
\hline Toplam & 400.2 & 323.2 & 452.6 & - & - & - & - & - & - \\
\hline
\end{tabular}


Çizelge 2. Deneme alanı toprak örneklerinde yapılan bazı kimyasal analiz sonuçları.

Table 2. Some chemical analysis results of experimental area.

\begin{tabular}{cccccccccc}
\hline $\begin{array}{c}\text { Derinlik } \\
(\mathrm{cm})\end{array}$ & $\begin{array}{c}\text { Toplam tuz } \\
(\%)\end{array}$ & $\mathrm{pH}$ & $\begin{array}{c}\text { Kireç } \\
(\%)\end{array}$ & $\begin{array}{c}\text { Fosfor }\left(\mathrm{P}_{2} \mathrm{O}_{5)}\right. \\
\left(\mathrm{kg} \mathrm{da}^{-1}\right)\end{array}$ & $\begin{array}{c}\text { Potasyum }\left(\mathrm{K}_{2} \mathrm{O}\right) \\
\left(\mathrm{kg} \mathrm{da}^{-1}\right)\end{array}$ & $\begin{array}{c}\text { Organik } \\
\text { madde }(\%)\end{array}$ & $\begin{array}{c}\text { Kum } \\
(\%)\end{array}$ & $\begin{array}{c}\text { Silt } \\
(\%)\end{array}$ & $\begin{array}{c}\text { Kil } \\
(\%)\end{array}$ \\
\hline $0-30$ & 0.130 & 7.43 & 5.75 & 3.75 & 110.0 & 1.04 & 22.01 & 28.95 & 47.52 \\
$30-60$ & 0.309 & 7.84 & 3.74 & 1.92 & 98.0 & 0.85 & 29.05 & 27.25 & 39.92 \\
\hline
\end{tabular}

\subsection{Materyal}

Araştırmada materyal olarak Ankara Üniversitesi Ziraat Fakültesi Tarla Bitkileri Bölümü'nden temin edilen İtalyan çiminin (Lolium italicum L. Syn. L. multiflorum Lam) Gemini, Tetraflorum ve Lolita çeşitleri kullanılmıştır. Azotlu gübre olarak amonyum nitratın (\% 33 N) 0 (kontrol), 4, 8, 12, 16, 20 ve $24 \mathrm{~kg} \mathrm{da}^{-1}$ saf azot dozları uygulanmıştır.

\subsection{Yöntem}

Araştırma, tesadüf blokları bölünmüş parseller deneme desenine göre 3 tekrarlamalı olarak planlanmıştır. Ana parsellere gübre dozları alt parsellere ise İtalyan çimi çeşitleri yerleştirilmiştir. Deneme alanı; her birinde 4 sıra olan $1.2 \mathrm{~m} \mathrm{x}$ $4.0 \mathrm{~m}$ ebadında 63 parsel, içerisinde 21 parsel olan aralarında $3 \mathrm{~m}$ boşluk bulunan ve toplamda $302.4 \mathrm{~m}^{2}$ yer kaplayan 3 bloktan oluşmuştur.

Ekim, erken ilkbaharda (15 Mart-15 Nisan) (Gençkan 1983; Eraç ve Ekiz 1985; Eraç ve Ekiz 1990) $30 \mathrm{~cm}$ sıra arası mesafe bırakılarak açılan sıralara el ile 3-4 cm derinliğe, dekara $4 \mathrm{~kg}$ tohumluk (Erkun ve ark. 1960) gelecek şekilde yapılmıştır. Azotlu gübrenin tamamı ekimle birlikte sıra aralarına saçılmış, tırmıkla toprak kapatılıp üzeri bastırılmıştır. İlave gübreleme yapılmamıştır. Çıkışa yardımcı olması için sulama yapılmıştır. Gelişen yabancı bitkilerle el ve çapa ile mücadele edilmiştir.

Türlere göre oldukça büyük değişimler görülmekle beraber, buğdaygil yem bitkilerinin başaklanma ile çiçeklenme arasında biçilmeleri genel kuraldır (Bakır 1987). Yeşil ot verimi Erkun ve ark. (1960)'a göre İtalyan çiminin en verimli ve besleyici olduğu başaklanma döneminde, biçilip tartılarak belirlenmiştir. Her parselden $500 \mathrm{~g}$ örnek alınarak $70^{\circ} \mathrm{C}$ 'de kurutulup tartılarak kuru ot verimleri tespit edilmiştir (Işsk 1990). Parsellerde belirlenen kuru ot verimleri ile laboratuar analizleri sonucunda bulunan ham protein içerik oranları çarpılarak ham protein verimi belirlenmiştir (Özaslan 2005). Ham protein içeriği Kacar (1972)'ın belirttiği esaslara göre Kjeldahl metoduyla belirlenmiştir. Kuru madde üretimini belirlemek üzere her parselden alınan numuneler, kuru ot değirmeninde ögütülmüş daha sonra bunlardan 0.3-0.5 g numune alınmıştır. Ham protein oranını tespit etmek için hazırlanan bu numunelerde yaş yakma metoduyla ottaki toplam azot oranı belirlenmiş ve toplam azot 6.25 katsayısı ile çarpılarak \% ham protein oranı hesaplanmıştır. Ham kül oranı tayini de Kacar (1972)'in belirttiği şekilde $105^{\circ} \mathrm{C}$ 'de kurutulmuş ve desikatörde soğutulmuş bitki örneklerinden alınan 2'şer gramlık numuneler, porselen potaya konularak $600{ }^{\circ} \mathrm{C}$ 'de 3 saat yakılmış, yakılan örnekler ile kalan kısmın oranlanmasıyla hesaplanmıştır. Asitte çözünmeyen lif (ADF) ve nötr deterjanda çözünmeyen lif (NDF) içerikleri Kutlu (2008)'ya göre hesaplanarak belirlenmiştir. Nispi yem değeri ADF ve NDF analiz sonuçları kullanılarak, Sindirilebilir Kuru Madde $(\mathrm{SKM})=88.9-(0.779 \mathrm{x}$ $\%$ ADF), Kuru Madde Tüketimi (KMT) $=120 /(\%$ NDF kuru maddede), Nispi Yem Değeri $(\mathrm{NYD})=(\mathrm{SKM}$ x KMT) $/ 1.29$ formülle hesaplanmıştır (Sheaffer ve ark. 1995).

Deneme, incelenen özelliklerin farklı iklim şartlarında değişimini görmek amaciyla 2 yıl olarak yürütülmüştür.
Araştırmada elde edilen tarla ve laboratuar gözlem ve ölçüm verileri, tesadüf bloklarında bölünmüş parseller deneme desenine göre bilgisayarda JMP (Kalayc1 2005) programında varyans analizine tabi tutulmuş ve değerlendirilmiştir. Ortalamaların karşılaştırılmasında, Duncan testi kullanılmıştır (Düzgüneş ve ark. 1987). Çoklu karşılaştırmalar $\mathrm{p}<0.05$ düzeyinde yapılmıştır.

\section{Bulgular ve Tartışma}

İç Anadolu bölgesinde Ankara şartlarında Gemini, Tetraflorum ve Lolita İtalyan çimi çeşitlerine uygulanan değişik azot dozlarının, ham protein oranı, protein verimi, ham kül oranı, asitte çözünmeyen lif (ADF) ve nötr deterjanda çözünmeyen lif (NDF) içerikleri ile nispi yem değerine (NYD) etkisine ilişkin iki yıllık birleştirilmiş sonuçlara ait olasılık (p) değerleri Çizelge 3 'te verilmiştir.

Çizelge 3 incelendiğinde görüleceği gibi azot dozları ham protein oranı, protein verimi, asitte çözünmeyen lif (ADF) ve nötr deterjanda çözünmeyen lif (NDF) içerikleri ile nispi yem değeri (NYD) üzerinde istatistiki olarak önemli $(p<0.01)$ olmuştur. Aynı şekilde çeşitler incelenecek olursa azot dozlarının ham protein oranı, protein verimi ve ADF içeriğinde önemli olmadığ 1 , ham kül oranında önemli $(p<0.05)$, NDF içeriği ve NYD üzerinde ise çok önemli $(p<0.01)$, olduğu görülmektedir. Çalışmada, y1l x azot dozu interaksiyonu ham protein oranı, ham kül oran1, ADF, NDF ve NYD üzerine istatistiki olarak önemli olmamış, protein veriminde istatistiki olarak önemli $(\mathrm{p}<0.01)$ olmuştur. Azot dozu $\mathrm{x}$ çeşit interaksiyonu ise ham protein oranı, ham kül oranı ve ADF özelliklerinde istatistiki olarak önemli olmamış, protein verimi, NDF ve NYD özellikleri üzerine önemli $(\mathrm{p}<0.05)$ bulunmuştur (Çizelge 3).

\subsection{Ham Protein Oranı (\%)}

Araştırmada elde edilen iki yıllık ortalama verilere göre Gemini, Tetraflorum ve Lolita İtalyan çimi çeşitlerinin ham protein oranlarının istatistiki olarak önemli olmadığ görülmüştür. Ham protein oranları Tetraflorum, Gemini ve Lolita çeşitlerinde sırasıyla \% 15.06 , \% 15.13 ve \% 15.22 olarak elde edilmiştir (Çizelge 4).

Azot dozu uygulamalarında ham protein oran1 \% 11.1717.40 arasında değişmiştir. En yüksek \% 17.40 ile 16, 20 ve $24 \mathrm{~kg} \mathrm{da}^{-1}$ azot dozu uygulamalarından, en düşük \% 11.17 ile azot uygulamasi yapilmayan $\left(0 \mathrm{~kg} \mathrm{da}^{-1}\right)$ kontrolden elde edilmiştir (Çizelge 5). Ham protein oranında kontrole göre 16 $\mathrm{kg} \mathrm{da}^{-1}$ azot uygulamasında \% 53 oranında artış sağlanmıştır.

Denemede elde edilen \% 11.17-17.40 arasındaki ham protein oranı sonuçları değerlendirildiğinde, USCTOFC (1982)'in \% 14.5, Karakurt ve Ekiz (1991)'in \% 13.58, Szyszkowska ve Sovinski (2001)'nin en düşük \% 7.54, en yüksek \% 21.99, ortalama \% 16.06 oranındaki, Kuşvuran ve Tans1 (2004)'nın \% 14.85-16.90, Simic (2009)'in \% 13.1-30.0, Kesiktaş (2010)'ın \% 12.5 ve Kuşvuran ve ark. (2014)'nın elde etmiş oldukları \% 13.0 oranındaki ham protein oranı verileri ile uyum içerisinde bulunduğu, Serin ve ark. (1996)'nın bulduğu 
$\%$ 17.78, Kallenbach (2003)'in \% 24.0, Akgün ve ark. (2008)'nın Erzurum'da yaptıkları araştırmadan elde ettikleri $\% 9.78$ ve Meeske ve ark. (2009)'nın araştırmaları sonucunda buldukları \% 21.1-22.8 ham protein oranı ile uyum sağlamadığ görülmektedir.

\subsection{Protein Verimi $\left(\mathrm{kg} \mathrm{da}^{-1}\right)$}

Denemede kullanılan İtalyan çimi çeşitlerinin iki yıllık ortalama protein verimleri değerlendirildiğinde; istatistiki olarak önemli olmadığ 1 , Tetraflorum çeşidinde 54.83, Gemini çeşidinde 55.55 ve Lolita çeşidinde ise $58.03 \mathrm{~kg} \mathrm{da}^{-1}$ protein verimi alındığı görülmektedir (Çizelge 4).

Farklı azot dozu uygulamalarında çeşitlerin protein verimleri 36.12-68.18 kg da ${ }^{-1}$ arasında değişmiştir. İlk azot uygulaması olan $4 \mathrm{~kg} \mathrm{da}^{-1}$ azot dozunda protein veriminde $\% 67$ oranında artış görülmüştür. Bundan sonra gelen 8,12 ve 16 $\mathrm{kg} \mathrm{da}^{-1}$ üç azot dozu uygulamasında benzer etki görülerek en yüksek protein verimi alınmıştır. $20 \mathrm{~kg} \mathrm{da}^{-1}$ azot uygulamasından itibaren protein veriminde düşüş başlamış ve en yüksek doz olan dekara $24 \mathrm{~kg}$ azot uygulamasında protein veriminde kontrol uygulaması ile aynı sonuç alınmıştır. En yüksek protein verimi 8,12 ve $16 \mathrm{~kg} \mathrm{da}^{-1}$ azot dozu uygulamalarından sirasıyla $66.55,68.18$ ve $67.27 \mathrm{~kg} \mathrm{da}^{-1}$ olarak elde edilmiş ve istatistiki olarak aynı grupta (a) yer almıştır. En düşük protein verimi $\left(36.12 \mathrm{~kg} \mathrm{da}^{-1}\right)$ ise kontrol $\left(0 \mathrm{~kg} \mathrm{da}^{-1}\right.$ azot dozu) uygulamasından elde edilmiştir (Çizelge 5). Protein veriminde $8 \mathrm{~kg} \mathrm{da}^{-1}$ azot dozu uygulamasında kontrole göre $\% 84$ oranında artış sağlanmıştır.

Araştırmadan elde edilen 36.12-68.18 $\mathrm{kg} \mathrm{da}^{-1}$ arasında değişen ham protein verimi, Çelen (1991)'in 64-92 kg da $\mathrm{kg}^{-1}$ ile Karakurt ve Ekiz (1991)'in $47.31 \mathrm{~kg} \mathrm{da}^{-1}$ ham protein verim ile aynı doğrultuda olmasına karşın, Başbuğ (1990)'un 128.7 $\mathrm{kg} \mathrm{da}^{-1}$, Serin ve ark. (1996)'nın $141.5 \mathrm{~kg} \mathrm{da}^{-1}$, Akgül (2001)'ün $79.8 \mathrm{~kg} \mathrm{da}^{-1}$, Kuşvuran ve Tansı (2004)'nın 182.97-231.88 kg $\mathrm{da}^{-1}$, Kesiktaş (2010)' 1 $92.4 \mathrm{~kg} \mathrm{da}^{-1}$ ve Kuşvuran ve ark. (2014)'nın $81.5 \mathrm{~kg} \mathrm{da}^{-1}$ ham protein verimi değerleri ile uyuşmadığ1 görülmektedir.

Çizelge 6'da verilen protein verimine ilişkin yıl x azot dozu interaksiyonu incelendiğinde, istatistiki olarak önemli $(\mathrm{p}<0.01)$ olduğu görülmektedir. Genel olarak araştırmanın ikinci yılında

Çizelge 3. İtalyan çimi çeşitlerinde farklı azot dozu uygulamalarının incelenen özelliklere etkisine ait (p) değerleri.

Table 3. Probability $(p)$ values regarding examined characteristic of different nitrogen doses applications on Italian rye grass cultivars.

\begin{tabular}{|c|c|c|c|c|c|c|}
\hline Varyasyon kaynağı & Ham protein oran 1 & Protein verimi & Ham kül oranı & Asit deterjan lif içeriği & Nötr deterjan lif içeriği & Nispi yem değeri \\
\hline Y1l & 0.8038 & $0.0001 * *$ & $0.0161 *$ & 0.0505 & 0.4731 & 0.9666 \\
\hline Blok (yıl) & 0.3034 & $0.0043 * *$ & 0.2563 & 0.3050 & 0.4152 & 0.3797 \\
\hline Azot Dozları & $0.0001 * *$ & $0.0001 * *$ & 0.0516 & $0.0011^{* *}$ & $0.0001 * *$ & $0.0001 * *$ \\
\hline Y11 x Azot Dozları & 0.3816 & $0.0006 * *$ & 0.2827 & 0.2558 & 0.9810 & 0.7898 \\
\hline Azot Dozları x Blok & 0.6348 & 0.0733 & 0.6954 & 0.8520 & 0.3045 & 0.1882 \\
\hline Çeşitler & 0.4989 & 0.1062 & $0.0195 *$ & 0.4139 & $0.0061^{* *}$ & $0.0057 * *$ \\
\hline Y1l x Çeşitler & 0.3435 & 0.4830 & 0.0564 & 0.9022 & 0.7279 & 0.7936 \\
\hline Azot Dozları x Çeşitler & 0.0776 & $0.0411 *$ & 0.4257 & 0.4003 & $0.0419 *$ & $0.0227 *$ \\
\hline Y11 x Azot Dozları x Çeşitler & 0.6910 & 0.2844 & 0.9826 & 0.9996 & 0.9730 & 0.9443 \\
\hline
\end{tabular}

*: 0.05 düzeyinde önemli. **: 0.01 düzeyinde önemli

Çizelge 4. İtalyan çimi çeşitlerinin incelenen özellikler bakımından iki yıllık ortalamaları ve önemlilik grupları.

Table 4. Two-year averages and the significance groups of traits on Italian ryegrass cultivars.

\begin{tabular}{|c|c|c|c|c|c|c|}
\hline Çeşit & Ham protein oran $1(\%)$ & Protein verimi $\left(\mathrm{kg} \mathrm{da}^{-1}\right)$ & Ham kül oranı (\%) & ADF içeriği (\%) & NDF içeriği (\%) & Nispi yem değeri \\
\hline$\overline{\text { Gemini }}$ & 15.13 & 55.55 & $9.86 \mathrm{~A}$ & 31.52 & $55.43 \mathrm{a}$ & $108.0 \mathrm{~b}$ \\
\hline Tetraflorum & 15.06 & 54.83 & $9.63 \mathrm{~B}$ & 31.31 & $55.07 \mathrm{ab}$ & $109.6 \mathrm{ab}$ \\
\hline Lolita & 15.22 & 58.03 & $9.73 \mathrm{AB}$ & 31.47 & $54.63 \mathrm{~b}$ & $109.9 \mathrm{a}$ \\
\hline
\end{tabular}

Aynı sütunda değişik küçük harflerle gösterilen ortalamalar arasında istatistiki olarak önemli farklılık vardır (p<0.05). Aynı sütunda değişik büyük harflerle gösterilen ortalamalar arasında istatistiki olarak önemli farkl1lık vardır $(\mathrm{p}<0.01)$.

Çizelge 5. Araştırmada uygulanan azot dozlarının incelenen özellikler bakımından iki yıllık ortalamaları ve önemlilik grupları.

Table 5. Two-year averages and the significance groups of treats of nitrogen doses used in the research.

\begin{tabular}{|c|c|c|c|c|c|c|}
\hline Azot dozu $\left(\mathrm{kg} \mathrm{da}^{-1}\right)$ & Ham protein oran $1(\%)$ & Protein verimi $\left(\mathrm{kg} \mathrm{da}^{-1}\right)$ & Ham kül oranı (\%) & ADF içeriği (\%) & NDF içeriği (\%) & Nispi yem değeri \\
\hline 0 & $11.17 \mathrm{e}$ & $36.12 \mathrm{c}$ & 9.66 & $31.63 \mathrm{ab}$ & $56.01 \mathrm{a}$ & $106.7 \mathrm{c}$ \\
\hline 4 & $13.29 \mathrm{~d}$ & $60.35 \mathrm{ab}$ & 9.54 & $31.12 \mathrm{~b}$ & $54.21 \mathrm{~b}$ & $110.9 \mathrm{a}$ \\
\hline 8 & $14.53 \mathrm{c}$ & $66.55 \mathrm{a}$ & 9.77 & $31.33 \mathrm{~b}$ & $55.29 \mathrm{ab}$ & $108.4 \mathrm{abc}$ \\
\hline 12 & $15.15 \mathrm{~b}$ & $68.18 \mathrm{a}$ & 9.79 & $32.08 \mathrm{a}$ & $55.25 \mathrm{ab}$ & $107.6 \mathrm{bc}$ \\
\hline 16 & $17.12 \mathrm{a}$ & $67.27 \mathrm{a}$ & 9.87 & $31.41 \mathrm{~b}$ & $55.86 \mathrm{a}$ & $107.3 \mathrm{bc}$ \\
\hline 20 & $17.40 \mathrm{a}$ & $55.73 \mathrm{~b}$ & 9.89 & $31.36 \mathrm{~b}$ & $54.53 \mathrm{~b}$ & $110.0 \mathrm{ab}$ \\
\hline 24 & $17.27 \mathrm{a}$ & $38.77 \mathrm{c}$ & 9.68 & $31.10 \mathrm{~b}$ & $54.14 \mathrm{~b}$ & $111.1 \mathrm{a}$ \\
\hline
\end{tabular}

Aynı sütunda değişik harflerle gösterilen ortalamalar arasında istatistiki olarak önemli farklılık vardır (p<0.01).

Çizelge 6. İtalyan çimi çeşitlerinde farklı azot dozu uygulamalarında protein verimine ilişkin yıl x azot dozu interaksiyonu.

Table 6. Interaction between nitrogen and year related to protein yield at different doses of nitrogen application in Italian ryegrass cultivars.

\begin{tabular}{|c|c|c|c|c|c|c|c|}
\hline \multirow[b]{2}{*}{ Y1l } & \multicolumn{7}{|c|}{ Azot dozu $\left(\mathrm{kg} \mathrm{da}^{-1}\right)$} \\
\hline & 0 & 4 & 8 & 12 & 16 & 20 & 24 \\
\hline 2008 & $34.45 \mathrm{~g}$ & 53.47 cdef & $54.40 \mathrm{cde}$ & $54.16 \mathrm{cde}$ & 54.95 cde & 48.50 defg & $37.93 \mathrm{fg}$ \\
\hline 2009 & $37.80 \mathrm{fg}$ & $67.24 \mathrm{abc}$ & $78.70 \mathrm{ab}$ & $82.16 \mathrm{a}$ & $79.59 \mathrm{a}$ & $62.95 \mathrm{bcd}$ & 39.60 efg \\
\hline
\end{tabular}

Değişik harflerle belirtilen ortalamalar arasında istatistiki olarak önemli farklılık vardır $(\mathrm{p}<0.01)$. 
(2009) birinci yıla (2008) göre daha yüksek protein verimi elde edilmiştir. En fazla protein verimi $12 \mathrm{ve} 16 \mathrm{~kg} \mathrm{da}^{-1}$ azot dozu uygulamalarında sirasıyla 82.16 ve $79.59 \mathrm{~kg} \mathrm{da}^{-1}$ olarak gerçekleşmiştir. En düşük protein verimi ise kontrol uygulamasından $34.45 \mathrm{~kg} \mathrm{da}^{-1}$ olarak elde edilmiştir (Çizelge 6). Her iki deneme yilında da 4, 8, 12 ve $16 \mathrm{~kg} \mathrm{da}^{-1}$ azot uygulama dozlarından benzer sonuçlar alınmış olduğu dikkat çekmektedir. Protein veriminde $4 \mathrm{~kg} \mathrm{da}^{-1}$ azot dozu uygulamasından sonra belirgin bir artı̧̧ görülmeye başlanmış, bu artış $16 \mathrm{~kg} \mathrm{da}^{-1}$ azot uygulamasına kadar etkili olmuş, $20 \mathrm{~kg} \mathrm{da}^{-1}$ azot uygulamasından itibaren düşmeye başlamıştır. En yüksek azot dozu uygulamasi olan $24 \mathrm{~kg} \mathrm{da}^{-1}$ da ise kontrol uygulamasina benzer etki görülmüştür (Çizelge 6).

Protein verimine ilişkin azot $\mathrm{x}$ çeşit interaksiyonu değerlendirildiğinde, istatistiki olarak önemli $(p<0.05)$ bulunmuştur. Çeşitlerin protein verimlerinde kontrol uygulamasına göre, $4 \mathrm{~kg} \mathrm{da}^{-1}$ azot dozu uygulamasından itibaren, 8,12 ve $16 \mathrm{~kg} \mathrm{da}^{-1}$ azot dozu uygulamalarında artış sağlanmıştır. $20 \mathrm{~kg} \mathrm{da}^{-1}$ azot dozu uygulamasından sonra protein veriminde azalış olmuştur. En yüksek dozda $\left(24 \mathrm{~kg} \mathrm{da}^{-1}\right)$ kontrol ile aynı etki elde edilmiştir. En düşük protein verimi kontrol uygulamasından alınırken, en yüksek protein verimi Tetraflorum çeşidinde $16 \mathrm{~kg} \mathrm{da}^{-1}$ azot dozu uygulamasında $73.47 \mathrm{~kg} \mathrm{da}^{-1}$ olarak gerçekleşmiştir (Çizelge 7).

\subsection{Ham Kül Oranı (\%)}

Çizelge 4'ün incelenmesinden de görüleceği gibi iki y1llık birleştirilmiş sonuçlara göre çeşitlerin ham kül oranı istatistiki olarak önemli $(\mathrm{p}<0.05)$ bulunmuştur. Ham kül oranı \% 9.639.86 arasında değişmiştir. En yüksek Gemini çeşidinde (\% 9.86), en düşük Tetraflorum çeşidinde (\% 9.63) elde edilmiştir. Lolita çeşidinden elde edilen ham kül oranı (\% 9.73) bu iki çeşit arasında yer almıştır. Değişik azot dozu uygulamaları çeşitlerin ham kül oranlarında istatistiki olarak önemli olmamıştır. Çeşitler arasında ham kül içerikleri bakımından \% 1-2 oranında değişim olduğu belirlenmiştir.

Ham kül içeriği sonuçları benzer çalışmalar ile karşılaştırıldığında, araştırmadan elde edilen \% 9.54-9.89'luk ham kül içeriğinin, Kuşvuran ve ark. (2014)'nın bulduğu \% 9.4 oranındaki ham kül içeriği ile uyum içerisinde olduğu, ancak Akgün ve ark. (2008)'nın \% 10.80 oranındaki ham kül değeri ile uyuşmadığı görülmektedir.

\subsection{Asit Deterjanda Çözünmeyen Lif (ADF) (\%)}

Araştırmada kullanılan İtalyan çimi çeşitlerinin iki yıllık ortalama ADF içerikleri değerlendirildiğinde istatistiki olarak önemli olmadığ 1 , ADF içeriğinin çeşitlere göre \% 31.31-31.52 arasında değiştiği görülmektedir. En yüksek ADF değeri (\% 31.52) Gemini çeşidinde, en düşük (\% 31.31) Tetraflorum çeşidinde belirlenmiştir. Lolita çeşidinin ADF içeriği (\% 31.47) ise bu iki çeşidin ADF değeri arasında gerçekleşmiştir (Çizelge 4).

Farklı azot dozu uygulamalarında çeşitlerin ADF içerikleri \% 31.10-32.08 arasında gerçekleşmiştir. En düşük ADF değeri $\% 31.10$ ile $24 \mathrm{~kg} \mathrm{da}^{-1}$ azot dozu uygulamasında, en yüksek ise $\% 32.08$ ile dekara $12 \mathrm{~kg}$ azot uygulamasında belirlenmiştir. ADF kapsamı değerleri arasında \%3 oranında değişim belirlenmiştir.

Araştırmadan elde edilen \% 31.10-32.08 arasındaki ADF sonucu, Teutsch ve Smith (2001)'in \% 18.7-25.0 arasindaki, Kallenbach (2003)'ın \% 22.0, Meeske ve ark. (2009)'nın \% 31.4-32.3 arasındaki ve Kuşvuran ve ark. (2014)'nın \% 37.4 oranındaki ADF oranı ile uyum sağlamadığı görülmektedir.

\subsection{Nötr Deterjanda Çözünmeyen Lif (NDF) (\%)}

Denemede ele alınan özelliklerden NDF içeriğine ilişkin iki y1llık ortalama değerler incelendiğinde, NDF verilerinin istatistiki olarak önemli $(\mathrm{p}<0.01)$ olduğu ve çeşitlere göre \% 54.63-55.43 arasında değiştiği görülmüştür. En yüksek NDF içeriği (\% 55.43) Gemini çeşidinde belirlenirken, en düşük NDF içeriği (\% 54.63) Lolita çeşidinde tespit edilmiştir. Tetraflorum çeşidinin NDF içeriği (\% 55.07) ise bu iki çeşidin NDF içeriği arasında gerçekleşmiştir (Çizelge 4).

Değişik azot dozu uygulamalarında çeşitlerin NDF içerikleri \% 54.14-56.01 arasında gerçekleşmiştir. En düşük NDF değeri (\% 54.14) $24 \mathrm{~kg} \mathrm{da}^{-1}$ azot dozu uygulamasında, en yüksek (\% 56.01) ise kontrol uygulamasında belirlenmiştir (Çizelge 5). NDF değerleri arasında \% 3 oranında değişim gerçekleşmiştir.

Denemede belirlenen \% 54.14-56.01 arasındaki NDF oranlar1; Viviani Rossi ve ark. (1994)'nın azotlu gübrenin 6 dozunu $\left(0,5,10,15,20,25 \mathrm{~kg} \mathrm{da}^{-1}\right)$ uygulayarak yaptıkları araştırma sonucunda elde ettikleri \% 47.7-54.7 arasındaki NDF değeri ile Teutsch ve Smith (2001)'in Virginia'da yaptıkları

Çizelge 7. İtalyan çimi çeşitlerinde farklı azot dozu uygulamalarında protein verimi, nötr deterjan lif ve nispi yem değerine ilişkin azot x çeşit interaksiyonu.

Table 7. Interaction between nitrogen and cultivars related to protein yield, neutral detergent fiber and relative feed value at different doses of nitrogen application in Italian rye grass cultivars.

\begin{tabular}{|c|c|c|c|c|c|c|c|c|}
\hline \multirow[b]{2}{*}{$\begin{array}{l}\text { İncelenen } \\
\text { özellikler }\end{array}$} & \multirow[b]{2}{*}{ Çeşit } & \multicolumn{7}{|c|}{ Azot dozu $\left(\mathrm{kg} \mathrm{da}^{-1}\right)$} \\
\hline & & 0 & 4 & 8 & 12 & 16 & 20 & 24 \\
\hline Protein & Gemini & $34.73 \mathrm{~h}$ & $56.18 \mathrm{def}$ & 64.97 abcde & $71.66 \mathrm{abc}$ & 62.73 abcde & 57.20 bcde & $41.38 \mathrm{fgh}$ \\
\hline Verim & Tetraflorum & $33.00 \mathrm{~h}$ & 60.34 abcde & 62.43 abcde & 63.03 abcde & $73.47 \mathrm{a}$ & $53.36 \mathrm{efg}$ & $38.21 \mathrm{gh}$ \\
\hline \multirow[t]{2}{*}{$\left(\mathrm{kg} \mathrm{da}^{-1}\right)$} & Lolita & $40.64 \mathrm{gh}$ & 60.54 abcde & $72.25 \mathrm{ab}$ & 69.85 abcd & 65.60 abcde & $56.63 \mathrm{cdef}$ & $36.71 \mathrm{~h}$ \\
\hline & Gemini & $56.86 \mathrm{a}$ & $54.56 \mathrm{abc}$ & $55.56 \mathrm{abc}$ & $55.16 \mathrm{abc}$ & $56.86 \mathrm{a}$ & $54.50 \mathrm{abc}$ & $54.50 \mathrm{abc}$ \\
\hline \multirow[t]{3}{*}{ NDF (\%) } & Tetraflorum & $55.75 \mathrm{abc}$ & $53.48 \mathrm{c}$ & $56.13 \mathrm{ab}$ & $55.30 \mathrm{abc}$ & $55.46 \mathrm{abc}$ & $55.36 \mathrm{abc}$ & $54.00 \mathrm{bc}$ \\
\hline & Lolita & $55.43 \mathrm{abc}$ & $54.60 \mathrm{abc}$ & $54.18 \mathrm{bc}$ & $55.30 \mathrm{abc}$ & $55.26 \mathrm{abc}$ & $53.73 \mathrm{c}$ & $53.93 \mathrm{bc}$ \\
\hline & Gemini & $105.0 \mathrm{e}$ & $110.3 \mathrm{abc}$ & 107.4 bcde & 107.8 abcde & $105.3 \mathrm{de}$ & $110.1 \mathrm{abcd}$ & $110.0 \mathrm{abcd}$ \\
\hline \multirow[t]{2}{*}{ NYD } & Tetraflorum & 106.9 cde & $112.4 \mathrm{a}$ & $107.0 \mathrm{cde}$ & $108.1 \mathrm{abcd}$ & 108.1 abcd & 108.5 abcde & $111.9 \mathrm{ab}$ \\
\hline & Lolita & 108.3 abcde & $110.1 \mathrm{abcd}$ & $111.2 \mathrm{abc}$ & $106.8 \mathrm{cde}$ & 108.4 abcde & $111.3 \mathrm{abc}$ & $111.3 \mathrm{abc}$ \\
\hline
\end{tabular}


araştırmada elde ettikleri \% 42.2-50.6 arasındaki NDF verileri ile paralellik göstermektedir. Meeske ve ark. (2009)'nın bildirdikleri \% 47.1-47.7 arasındaki NDF sonucu ve Kuşvuran ve ark. (2014)'nın araştırmalarından alınan \% 58.7'lik NDF değeri ile uyum içinde olmadığı görülmektedir.

Nötr deterjanda çözünmeyen lif (NDF) içeriğine ilişkin azot $\mathrm{x}$ çeşit interaksiyonu verilerine bakıldığında, istatistiki olarak önemli $(\mathrm{p}<0.05)$ olduğu görülmektedir. Her üç çeşitte de kontrol uygulamasında yüksek NDF içeriği belirlenmiştir. Gemini çeşidinde en yüksek NDF oranı kontrol ve $16 \mathrm{~kg} \mathrm{da}^{-1}$ azot dozunda elde edilirken, diğer 4, 8, 12, 16 ve $24 \mathrm{~kg} \mathrm{da}^{-1}$ azot dozlarında aynı etki görülmüştür. Tetraflorum çeşidinde ilk azot dozu uygulaması olan $4 \mathrm{~kg} \mathrm{da}^{-1} \mathrm{da}$ en düşük NDF oranı belirlenmiştir. Diğer azot uygulama dozlarına benzer tepkiyi göstermiştir. Lolita çeşidinde ise en düşük NDF değeri dekara $20 \mathrm{~kg}$ azot dozu uygulamasında, en yüksek ise kontrol uygulamasında elde edilmiştir (Çizelge 7).

\subsection{Nispi Yem Değeri (NYD)}

Çalışmada ele alınan kriterlerden Nispi Yem Değerine ilişkin iki yıllık ortalama veriler incelendiğinde, NYD verileri arasındaki farkların istatistiki olarak önemli $(\mathrm{p}<0.01)$ olduğu ve çeşitlere göre 108.0 ile 109.9 arasında değiştiği görülmüştür. En yüksek NYD (109.9) Lolita çeşidinden belirlenirken, en düşük NYD (108.0) Gemini çeşidinde bulunmuştur. Tetraflorum çeşidinin NYD (109.6) değeri ise bu iki çeşidin verileri arasında gerçekleşmiştir (Çizelge 4).

Farklı azot dozu uygulamalarında çeşitlerin NYD verileri 106.7 ile 111.1 arasında gerçekleşmiştir. En yüksek NYD (110.9 ve 111.1) dekara 4 ve $24 \mathrm{~kg}$ azot dozu uygulamalarında, en düşük NYD (106.7) kontrol uygulamasında elde edilmiştir (Çizelge 5). NYD verileri arasında \% 4 oranında değişim olduğu belirlenmiştir.

Araştırma sonucunda 106.7-111.1 arasında belirlenen nispi yem değeri (NYD), Kuşvuran ve ark. (2014)'nın İtalyan çiminin Caramba çeşidinden elde ettikleri 94 NYD değerinden yüksek olmuştur.

Nispi yem değerine (NYD) ilişkin azot $\mathrm{x}$ çeşit interaksiyonu istatistiki olarak önemli $(\mathrm{p}<0.05)$ olmuştur. Çeşitlerin en düşük NYD verileri gübre kullanılmayan kontrol uygulamasında elde edilmiştir. Tetraflorum ile Gemini çeşitlerinde ilk azot dozu uygulaması olan $4 \mathrm{~kg} \mathrm{da}^{-1}$, da en yüksek nispi yem değerine ulaşılmıştır (Çizelge 7).

\section{Sonuç}

Orta Anadolu bölgesinde kuru (sulama yapılmaksızın) şartlarda İtalyan çimi yetiştiriciliğinde daha yüksek verim ve kaliteli ürün elde etmek için kullanılması gereken azotlu gübre miktarını belirlemek amacıyla, iki farklı yılda yapılan bu çalışmanın sonuçlarına göre benzer şartlarda yapılacak yetiştiricilikle ilgili aşağıdaki önerilere ulaşılmıştır. Yağışın daha az olduğu ekolojilerde veya dönemlerde, 4 veya $8 \mathrm{~kg} \mathrm{da}^{-1}$ azotlu gübre kullanmak, verimi önemli derecede attırmaktadır. Azotlu gübrelerin daha fazla verilmesi, verim ve kaliteye etki eden özelliklerde anlamlı bir yükselme sağlamadığı gibi, genel olarak yüksek azotlu gübre dozları İtalyan çiminde yem verimini azaltıcı etki göstermektedir. Yağışın nispeten iyi olduğu ekolojilerde veya dönemlerde $8 \mathrm{~kg} \mathrm{da}^{-1}$ azotlu gübre kullanmak birim alandan en yüksek kuru ot verimi alınmasını sağlamıştır. Yüksek dozlarda (20 ve $24 \mathrm{~kg} \mathrm{da}^{-1}$ ) verilen azotlu gübreler, İtalyan çiminin ot verimini olumsuz yönde azaltıcı bir etkiye sahip olmuştur.

\section{Kaynaklar}

Akgül F (2001) Ankara şartlarında farklı sıra aralığı ile ekim ve azotla gübrelemenin tek yıllık çim (Lolium multiflorum Lam.)' in ot verimi ve kalitesine etkileri. Yüksek Lisans Tezi, Çanakkale On Sekiz Mart Üniversitesi Fen Bilimleri Enstitüsü, Çanakkale.

Akgün İ, Tosun M, Şengül S (2008) Comparison of agronomic characters of festulolium, festuca pratensis Huds. and Lolium multiflorum Lam. genotypes under high elevation conditions in Turkey. Bangladesh Journal Botany 37(1): 1-6.

Bakır Ö (1987) Çayır-Mera Amenajmanı. Ankara Üniversitesi Ziraat Fakültesi, Ders Kitabı Yayın No: 992, s. 362, Ankara.

Başbuğ S (1990) Bursa şartlarında bazı çok yıllık ve tek yıllık buğdaygil yem bitkilerinin ot verimi ve kalitesi üzerine araştırmalar. Yüksek Lisans Tezi, Uludağ Üniversitesi Fen Bilimleri Enstitüsü, Bursa.

Baytekin H, Kızılşimşek M, Demiroğlu G (2009) Çim ve Ayrık Türleri. (Ed: Avcioğlu R, Hatipoğlu R, Karadağ Y) Yem Bitkileri Genel Bölüm Cilt III. Tarım ve Köyişleri Bakanlığı Tarımsal Üretim ve Geliştirme Genel Müdürlüğü, İzmir, s. 561-572.

Çelen AE (1991) Ege bölgesi koşullarında İtalyan çimi (Lolium multiflorum var. westerwoldicum)'nden yararlanma olanakları. Türkiye II. Çayır Mera ve Yem Bitkileri Kongresi İzmir, s. 424429.

DMİGM (2009) Devlet Meteoroloji İşleri Genel Müdürlüğü. Aylık iklim rasat cetveli, Ankara.

Düzgüneş O, Kesici T, Kavuncu O, Gürbüz F (1987) Araştırma ve Deneme Metotlar1. Ankara Üniversitesi Ziraat Fakültesi, Ders Kitabı Yayın No: 1021, s. 381, Ankara.

Eraç A ve Ekiz H (1985) Yem Bitkileri Yetiştirme. Ankara Üniversitesi Ziraat Fakültesi, Yayın No: 1164, Ankara.

Eraç A, Ekiz H (1990) Yem Bitkileri Yetiştirme. Ankara Üniversitesi Ziraat Fakültesi, Yayın No: 964, s. 16, Ankara.

Erkun V, Bakır Ö, Alınoğlu N (1960) Çayır, Mera ve Yem Nebatları. Ziraat Vekaleti Meslek Kitapları Serisi D12, s. 216, Ankara.

Eyüpoğlu F (1999) Türkiye topraklarının verimlilik durumu. Köy Hizmetleri Genel Müdürlüğ̈̈ Toprak-Gübre Araştırma Enstitüsü Müdürlüğü, Genel Yayın No: 220, Ankara.

Gençkan MS (1983) Yem Bitkileri Tarımı. Ege Üniversitesi Ziraat Fakültesi, s. 520, İzmir.

Güneş A, Alpaslan M, İnal A (2010) Bitki Besleme ve Gübreleme. Ankara Üniversitesi Ziraat Fakültesi, Ders Kitabı Yayın No: 1581, s. 533, Ankara.

Işık BS (1990) Değişik azot dozlarının doğal çayırın yem verimi ve botanik kompozisyonuna etkileri üzerine araştırmalar. Yüksek Lisans Tezi, Ankara Üniversitesi Fen Bilimleri Enstitüsü, Ankara.

Kacar B (1972) Bitki ve Toprağın Kimyasal Analizleri. II. Bitki Analizleri. Ankara Üniversitesi Ziraat Fakültesi, Yayın No: 453, Ankara.

Kalaycı M (2005) Örneklerle jump kullanımı ve tarımsal araştırma için varyans analiz modelleri. Anadolu Tarımsal Araştırma Enstitüsü Müdürlüğü, Yayın No: 21, Eskişehir.

Kallenbach R, Massie M, Crawford R (2003) Nitrogen fertilization strategies for annual ryegrass pastures. University of Missouri Extension.

Karakurt E, Ekiz H (1991) İskenderiye üçgülü (Trifolium alexandrinum L.) ile İtalyan çimi (Lolium multiflorum Lam.) karışım oranlarının ot verimine etkisi. Ankara Üniversitesi Ziraat Fakültesi, 1999(44) 97-104. Ankara.

Kesiktaş M (2010) Karaman'da farklı ekim zamanları ve azotlu gübre dozu uygulamalarının İtalyan çimi (Lolium multiflorum westervoldicum cv. caramba)'nin yem verimlerine etkileri. Yüksek Lisans Tezi, Çukurova Üniversitesi Fen Bilimleri Enstitüsü, Adana. 
Kuşvuran A, Tansı V (2004) Cukurova koșullarında farklı sıra aralıklarının tek yıllık çim (Lolium multiflorum cv. caramba)'in ot ve tohum verimine etkisi üzerine bir araştırma. Çukurova Üniversitesi Bilimsel Araştırma Projeleri Birimi ZF/2002/BAP/72 Nolu Proje Sonuç Raporu, Adana.

Kuşvuran A, Kaplan M, Nazlı Rİ (2014) Effects of ratio and row spacing in hungarian vetch (Vicia pannonica Crantz.) and annual ryegrass (Lolium multiflorum Lam.) intercropping system on yield and quality under semi arid climate conditions. Turkish Journal of Field Crops, 19(1): 118-128.

Kutlu HR (2008) Yem değerlendirme ve analiz yöntemleri ders notu. Cukurova Üniversitesi Ziraat Fakültesi Zootekni Bölümü, Adana http://www.zootekni.org.tr. Erişim12 Haziran 2014.

Meeske R, Botha PR, Van Der Merwe GD, Greyling JF, Hopkins C, Marais JP (2009) Milk production potential of two ryegrass cultivars with different total non-structural carbohydrate contents. South African Journal of Animal Science, 39(1).

Özaslan A (2005) Bazı yapay mera karışımlarında ekim yöntemleri ve azot dozlarının yem verimi ve kalitesine etkileri. Doktora Tezi. Ankara Üniversitesi Fen Bilimleri Enstitüsü, Ankara.

Özkul H, Kırkpınar F, Tan K (2012) Ruminant beslemede Karamba (Lolium multiflorum cv. caramba) otunun kullanımı. Hayvansal Üretim 53(1): 21-26.

Sabancı CO, Baytekin H, Balabanlı C, Acar Z (2010) Yem bitkileri üretiminin artırılması olanakları. Ziraat Mühendisliği VII. Teknik Kongresi Cilt I. s. 343-359. TMMOB Ziraat Mühendisleri Odas1, Ankara.

Serin Y, Tan M, Seker H (1996) Azotla gübreleme ve ekim oranının tek yılık çim (Lolium multiflorum Lam.)'de ot ve ham protein verimi ile otun ham protein oranına etkileri. Türkiye III. Çayır Mera ve Yem Bitkileri Kongresi, Erzurum, s. 732-738.

Serin Y, Tan M (1999) Buğdaygil Yem Bitkileri Tarımı. Çayır Mera Amenajmanı ve Islahı. Tarım ve Köyişleri Bakanlığı, Yayın No: 1, Ankara, s. 35-47.
Sheaffer CC, Peterson MA, McCaslin M, Volenec JJ, Cherney JH, Johnson KD, Woodward WT, Viands DR (1995) Acid detergent fiber, neutral detergent fiber concentration and relative feed value. Available from URL: https://www.umvotiagri.co.za/linked/adf $\% 20$ ndf\%20in\%20silage.pdf. Erişim 23 Aralık 2014.

Simic A, Vuckovic S, Kresovic M, Vrbnicanin S, Bozic D (2009) Changes of crude protein content in Italian ryegrass influenced by spring nitrogen aplication. Bioteknology in Animal Husbandry 25 (5-6): 1171-1179. Belgrade - Zemun Serbia.

Szyszkowska A, Sowinski J (2001) Botanical composition and nutritional value of two-component mixtures containing red clover and different grass species. Wydawnictwo Akademi Rolniczejwe Wroclawiu, ISSN 1505-0297.

Teutsch C, Smith R (2001) Does annual ryegrass fit into Virginia's pasture systems? Crop and soil environmental news, September, USA.

TÜIKK (2015) Tarımsal istatistikler veri tabanı. T.C. Başbakanlık Türkiye İstatistik Kurumu, Ankara, www.tuik.gov.tr. Erişim 31 Ocak 2017

USCTOFC (1982) United States-Canadian Tables Of Feed Composition. Nutritional Data For United States and Canadian Feeds. Third Revision, National Academy Press, Washington D.C.

Viviani Rossi EM, Gutierrez LM, Moreno E, Mazzanti A (1994) Nitrogen fertilizer effects upon silage composition and quality of Lolium multiflorum L. CC 276(7620) Argentina.

Yavuz M, İptaş S, Ayhan V, Karadağ Y (2009) Yem Bitkilerinde Kalite ve Yem Bitkilerinden Kaynaklanan Beslenme Bozuklukları (Ed Avcioğlu R, Hatipoğlu R, Karadağ Y) Yem Bitkileri Genel Bölüm Cilt I.Tarım ve Köyişleri Bakanlığı Tarımsal Üretim ve Geliştirme Genel Müdürlüğü, İzmir, s. 163-172.

Zabunoğlu S, Karaçal İ (1986) Gübreler ve Gübreleme. Ankara Üniversitesi Ziraat Fakültesi, Ders Kitabı Yayın No: 993, Ankara. 